\title{
Acting and Collecting: Imagining Asia through material culture and musical theatre
}

\author{
Peter Thorley*
}

\begin{abstract}
This paper explores the link between Asian-inspired material culture and musical theatre through the collections of Anglo-Australian performer Herbert Browne (18951975). Brown played lead roles in 1920s Australian musical theatre productions of The Mikado and Chu Chin Chow and re-lived his connection with oriental theatre by collecting and responding to objects performatively in the Chinoiserie room of his Melbourne home. Oriental musical theatre blended exotic cultures and locales in visually spectacular productions which bore little resemblance to reality. The taste for escapist fiction in the theatre took place against a backdrop of museum collecting which aimed to reproduce authentic Asian and Other cultures. In this paper, I draw on French philosopher Merleau-Ponty's observations on the relationship between thought and the body's interaction with space to interpret the influence of Browne's theatricality on collecting choices. From this perspective, objects materialize particular understandings of the world which originate in the body and the body's performative engagement with space.
\end{abstract}

Key words: museums, orientalism, performance, collections.

As national and ethnic distinctions become increasingly porous, medium-, nation-, and ethnic-specific collecting become problematic. But during periods of historical change, problematic categories still must be discussed in older terms, at the same time as their validity is questioned and new terminology and practices are formulated. Museums now find themselves at such a historical juncture ... (Altshuler 2007: 9)

Since they first appeared in Europe, collections representing Asia have figured prominently in the private and public imaginary. Museums occupy an important place in this history as repositories for objects and as a space for public display and scholarly contemplation. Collectors of Asian material culture ranged across a spectrum from specialists, often aligned to museums, with a focus on specific cultures and types, to those with more eclectic and individual tastes whose primary reason for collecting was domestic display (Shelton 2001). Specialist collectors were instrumental in the development of museum collections through donations and bequests and actively shaped the status and market value attached to particular objects (Myers 2001, Pierson 2007). On the other hand, objects intended for popular consumption and home display tended to be assigned a lower value by specialists, and were less likely to enter the hallowed spaces of museum halls. Nonetheless, objects of this type continued to be used widely outside museums where they served to mediate perceptions of distant encounters with 'Asia'.

One example of a collection which transcended the boundaries and categorical imperatives of museums and specialist Asian collectors was a group of objects assembled by Herbert Browne (1895-1975), an entertainer of English origin who migrated to Australia in 1921 (Plate 1). Herbert Browne's daughter, Maggie, who grew up in the family home in suburban Melbourne, recalls how his collections were displayed:

In our Essendon house there was a little room where Dad kept his oriental collection. It was covered in gold wallpaper and in the corner was a black divan with a large gong. Dad called this 'the Chinese Room'. When people would come around for drinks, Dad would light some incense and say 'Come in and have a cocktail, darlings'. ${ }^{1}$ 


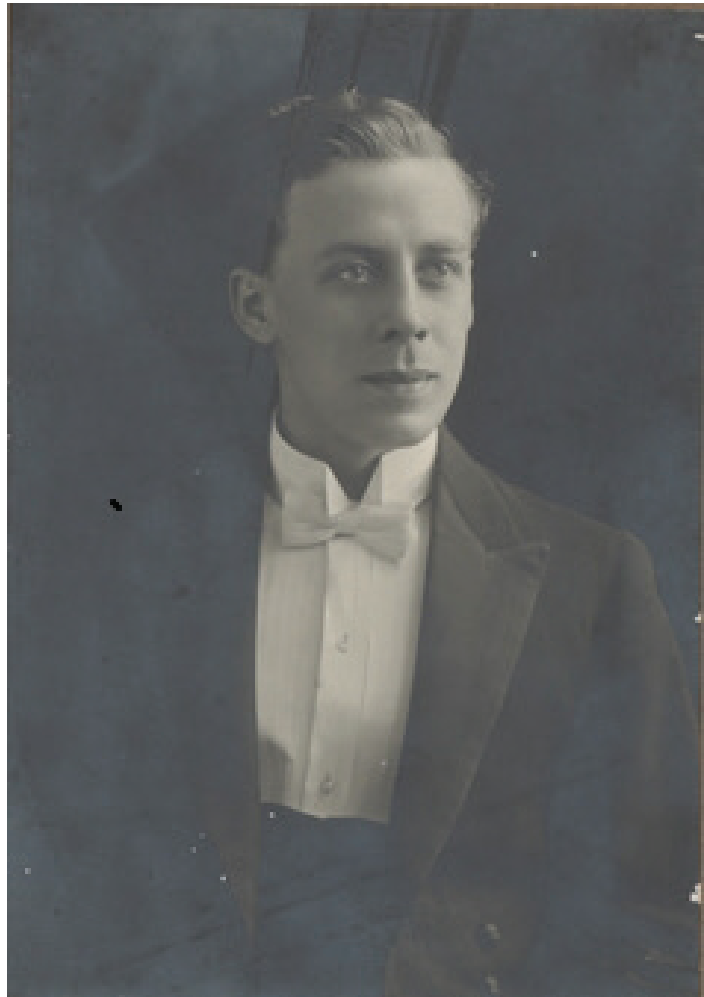

Plate 1. Herbert Browne 1922, National Museum of Australia. height of refined taste, Chinoiserie and orientalism were not exclusively high fashion. Musical theatre was a case in point, one of its primary influences being music hall, a form of variety entertainment usually performed in working class public houses.

In musical theatre, it was the combination of spoken dialogue, song and dance that made possible the dissemination of its familiar tropes such as the conflation of Asia and Middle East as generally oriental and hence exotic. Musical theatre created its own unashamedly populist blend of orientalist fantasy that catered to a desire for escapism during the First World War and the inter-war period (Everett 2007). One of the leading proponents of orientalist musical theatre during this period, Australian born and educated Oscar Asche, performed alongside Browne in the 1923 Australian production of Chu Chin Chow.

The acquisition of Browne's collection by the National Museum of Australia (NMA) in 2007 reflects a shift in the frame through which cultural collections have traditionally been collected and interpreted. The collection and display of objects as material expressions of culture propagated a knowledge about Asia that supported Europe's global military and economic expansion (Said 1978). Further, museums instilled a belief that cultures could be depicted accurately and scientifically, promoting the ideal of the 'authentic exotic' (Desai 2007). These arguments have led to a redefinition of the role of museums in representing Asian and Other cultures. Indeed, the acquisition of Browne's collection by the NMA is an example of the repositioning of museums in relation to conventional trajectories of collecting.

The NMA was created in 1980 and soon after began building a collection through donation, purchase and transfer from Australian government agencies. Its doors were opened to the public in 2001 with the completion of an ultra-modern building in Canberra to house its exhibitions. Faced with the challenge of building its collection virtually from scratch, acquisition has been a priority for the museum since its establishment. 
As an emerging institution, the NMA was not wedded to a legacy of collecting practice in the manner of its more established counterparts. In its formation the NMA was able to avoid the cultural hierarchies imposed by past museums, as reflected in the organizational structures of museums created during the colonial era. For example, as Bolton (2008) noted, until recently Asian art at the British Museum was divided into separate collections and departments: the Oriental Antiquities Department, responsible for higher-ranked forms of Asian art, such as stone sculptures and examples of 'palace and temple art' and the Ethnography Department, which looked after the lesser-ranked pottery, baskets, wooden items and textiles. The two have recently been merged into a single department: 'Asia'. As Tythacott (2011: 12) observed, the classifiers 'Asian' and 'Oriental' imbue collections with particular connotations which have become ingrained in institutional practices.

The methods applied to material culture collections of the nineteenth century borrowed heavily from the physical sciences and ideas circulating at the time regarding the biological origins of cultural difference (Bennett 2004, Tythacott 2001). Museum displays of the time classified and displayed collections of objects and human remains in accordance with emerging anthropological approaches. Aboriginal collections were placed at the lowest rung of the evolutionary ladder and were considered as existing outside the category of 'art'. While collections of the colonial era may have been tainted by racialized modes of enquiry, a range of curatorial and research strategies have emerged which allow them to be cast in a different light (eg O'Hanlon and Welsch 2000, Shelton 2001, Peterson et al. 2008).

The challenge for museums is not to authentically recreate culture in the museum space but rather to apply criteria to the selection of objects and exhibitionary practices which will allow audiences to see through the representations to the authentic social life behind them. In the twentieth century, many nations emerged from the colonial period looking to develop museums of their own and to reclaim their cultural patrimony, in response to having been collected and represented in colonial museums. Ironically, the emphasis on the traditional and ancient as symbols of national identity saw the assumptions of colonial museums of the nineteenth century reproduced in the twentieth century when emerging national museums sought to represent their own cultures (Lockyer 2008, National Museum of China 2011). Objects produced for local consumption were elevated and distinguished from those produced for sale or export (Pierson 2007, Philips and Steiner 1999). The notion of cultures as somehow pure, bounded and timeless suited the goals of both emerging national collections as well as those with nineteenth century roots. New approaches to material culture began to be fashioned in the latter part of the twentieth century, but as Desai (2007) observes, changes within the collecting structures of museums and galleries have struggled to keep apace.

The NMA has a relatively short history, although it too has inherited collections from the colonial era and their associated assumptions. The Australian Institute for Anatomy was previously responsible for holding the Nation's ethnographic collections from Aboriginal Australia and Papua and New Guinea. These collections passed to the NMA when the Institute was dissolved in 1985. They included many artefacts once deemed to be authentic cultural types, but which on re-examination reveal a history of inter-cultural production, collaboration and collusion between makers and collectors. The co-existence of ethnographic and natural science collections is also preserved in the structure of the older provincial museums in the two largest Australian state capitals. The Australian Museum in Sydney was founded in 1845 and the National Museum of Victoria in 1854, at a time when the study of human culture was beginning to emerge as a branch of the natural sciences in Europe. Both institutions encompass flora, fauna, and geology along with ethnographic collections in their collecting remit.

The NMA was established in a very different intellectual climate to nineteenth century Australian museums in the state capitals. The development of the Museum's unique perspective can be seen through its exhibitionary practices where emphasis has been placed on social history, multiple perspectives and the emotions in Australian life. In addition to foregrounding Indigenous perspectives, its permanent galleries explore themes of identity, interconnections between people and place and transnational history. One of its galleries is devoted solely to contemplation of the affective domain through personal stories and objects. In seeking to avoid a didactic interpretation of the nation's past, the NMA's exhibitions focus on the specificity of individual lives through object displays which capture subjective experiences of Australia and its place in the world. 


\section{The Chinoiserie Room of Herbert Brown}

The NMA's Herbert Browne collections consists of 334 items which include Aboriginal artefacts, paper-based materials (documents, photographs and theatrical programs) and items pertaining to his theatrical make-up business (NMA collection numbers 2006.0097 and 2008.0044). Of these, 31 objects are referred to here as the 'Chinese Room collection' (Table 1). The objects combine traditional crafts, modern designer wares and materials illustrating various religious and spiritual themes that span many regions, cultures and nationalities.

\begin{tabular}{|l|l|l|}
\hline Object type & Quantity & Materials \\
\hline Bookends & 2 pairs & brass, wood/lacquer \\
\hline Bowls & 2 & lacquer \\
\hline Containers & 5 & lacquer \\
\hline Cup and saucer & 1 set & lacquer \\
\hline Bell/striker (incl. gongs) & 3 & metal, wood/metal \\
\hline Incense & 2 & aromatic plant material, dyes \\
\hline Incense burner & 1 & metal \\
\hline Ornaments & 7 & brass, wood, glass, plastic \\
\hline Smoking pipes & 2 & steel, brass, woven fibre \\
\hline Trays & 3 & lacquer \\
\hline Vase & 1 & brass \\
\hline Cocktail glasses & 3 & lacquer \\
\hline
\end{tabular}

Table 1. Summary of objects in Herbert Browne's 'Chinese Room' Collection

Along with his Aboriginal collection, which was displayed in a separate, though adjacent room, the objects held in Browne's family home speak of cultural encounters in many places and forms. Rather than representing individual authentic types, to Browne, the objects supported a generalised image of Asia and in this respect were wedded with Browne's public and private performances.

Browne's collecting interests were not constrained by type or specific places of origin. Although bundled together as Chinese, objects held within this space display identifiable motifs and influences from Japan, China and other locations. His imagined Asia maps out a broad region with overlapping boundaries, the geographic centre of which was China and Japan although in Browne's room the two become generically 'Chinese'.

The Chinese room also contained objects depicting the Middle East, such as a castmetal incense burner moulded in the shape of a woman lying face down with an Egyptian style headdress.

In his collections, Browne did not attempt to separate out the 'Asian' from 'Middle Eastern'. In this respect, it is possible to see the influence of his immersion in theatrical orientalism through performances such as Chu Chin Chow which combined Arabic and Chinese influences.

Like other artists and musicians of his time, Browne was fascinated by the 'mystic East' which resonated with his orientalist theatrical background (Richards 2007, Cheang 2001). In his private life Browne dabbled in séances and astrology (his astrological chart was acquired by the NMA as part of the collection). Within the context of the home, the burning of incense and the display of iconic religious objects reinforced a view of Asia as a spiritual heartland. His fondness for Buddha statues and imagery was in keeping with his interest in spiritualism, yet the objects themselves incorporate modern twentieth-century design and non-traditional materials such as plastic and glass, which run contrary to the idea of Asia as ancient and timeless. His collections include a wooden Buddha, of the 'laughing Buddha' form, two seated Buddhas made from synthetic and moulded materials; one of coloured glass and the other of plastic, and a pair of metal book ends in the form of a seated Buddha.

Browne was not a practicing Buddhist and thus the meanings he ascribed to figures of the Buddha derived as much from their association with a pan-Asian orientalism as a religious 
faith (Harris 2006). While Buddha figures such as those assembled by Browne and held in the NMA collection are among the most collectable forms of Asian art in the twentieth century, mass-produced types are seldom encountered in museum collections or displays. The spiritual eternalism conveyed by images of the Buddha, including those manufactured by modern materials such as plastic and glass, has led to their widespread adoption in modern interiors, yet rather than historicize the process of adaptation, modern production has contributed to these objects achieving iconic status in representing Asia as ancient and timeless.

The eclecticism in Browne's collection is also evident in the way in which it combines different classes of objects and forms of art. Browne's Japanese lacquer ware and Chinese carved wooden qilin and lohan figurines seem slightly incongruous alongside the massproduced religious icons seen elsewhere in his collection. The level of detail in the carved figures suggests Browne had a taste for objects displaying craftsmanship by individual artists or small-scale factory production. What is important to note is that, in their display, Browne appeared to make no attempt to single out the 'fine-art' products from the standardized factory items or 'manufactures'.

Many of the objects in Browne's collection are utilitarian and decorative, such as cocktail glasses and bookends. These objects combine iconic imagery - Buddhas, cherry blossoms and the like - with modern functional design. In a contemporary sense, these objects typify what are commonly referred to as 'homewares'. The Buddha is also referenced in a pair of cast-metal bookends seated amidst a background of trees, mountain and temple. The style of landscape referenced suggests Japanese rather than Chinese cultural origin. This piece and a brass vase with a Chinese dragon design are typical of modern designer home wares, mass-produced for domestic and export markets.

Gold is prevalent in the décor of Browne's Chinoiserie parlour on the walls of the room as in the objects themselves, particularly the lacquerware. An assortment of small lacquered beakers in Browne's collection have been hand decorated with Rinpa ${ }^{2}$ inspired designs on gold background. Popular styles of lacquer displaying elements of modern Japanese design may have been produced for export in China which had its own well-established lacquer industry. Objects which display a Japanese or Chinese aesthetic could conceivably have been produced elsewhere in an attempt to supply a Western market. Such objects defy categorization in terms of location of origin and highlight the complex interactions of production and consumption locales.

For Browne, however, there was less concern for authenticity, for a particular culturehistorical type, than the overall appearance of a generic 'Asia'. This cultural fetishism was achieved through a combination of styles rather than a differentiation of specific types and places of origin. This re-combining of cultural elements from multiple places of origin can be seen in Browne's pair of matching ornamental gongs, one of which appears more Chinese in style, the other resembling Shinto architecture. The two gongs have identical bells with a painted Chinese dragon design, yet hang from distinctly different 'gates' which combine to imply a more generic 'Asian' appearance. Given the high degree of cross-fertilization of styles and the proliferation of modern manufacturing locales, identifying culture of origin for objects of this type is highly problematic. Nonetheless, they are in keeping with the inter-cultural products that re-occur throughout Browne's Asian collection.

Some of the items in the collection may have come to Browne as props from musical theatre productions in which he performed. Among the eclectic items collected by Browne were two smoking pipes. One is a metal water pipe, the other wooden, with a brass bowl and mouthpiece. In one sense, these objects appear more closely aligned with ethnographic objects in a museum collection. But like his 'fine-art' objects, placed alongside the other objects in Browne's assembly, they are reinscribed within his own representational frame.

It is possible that objects such as these could have been acquired from the props department of JC Williamsons, the company which employed Browne. If this were the case, their link with the theatre would be direct, as material reminders of Browne's past experience. Whether or not he souvenired props from productions in which he performed as mementos of his musical theatre experiences is unclear. Nonetheless, there is a definite association between his home display of his Chinoise-styled collections and the musical theatre productions in which he performed. Collectively, the objects represent an imagined Asia that, for Browne, is tied up with the theatre, regardless of type, age or nationality. Browne's attachment to Asia, as 
seen through his collection, was universalist and non-discriminatory - very much the way Asia tended to be represented in fashionable musical theatre productions of the time. Browne's homeware collection was selected and fashioned to reflect these interests.

Though representing an essentialized view of material culture in the manner suggested by Said (1978), Browne's Asian collections have potential for reinterpretation. Rather than exemplars of specific cultures of origin, their manufacture speaks of developing economies within Asia expanding their role within a globalizing economy. The objects reveal exchanges between producers as well as in the relationship between producers and consumers. Moreover, the way in which Browne's collection functioned within his own cultural environment allows insights into the Anglo-Australian imaginary in the early twentieth century.

\section{Entertaining, Cultural Display and the Home}

Browne's Essendon home was also the display venue for his prized assembly of Aboriginal artefacts (NMA collection number 2006.0097) which he had acquired from his travels across the Nullarbor Plain on the edge of the Great Victoria Desert in southern Australia. Browne's Aboriginal collection is more fixed in its location and community of origin, which he had passed through as a traveller, although it too is imbued with a timelessness exempt from history which Edward Said (1978) attributed to orientalism. As a touring artist, Browne came into contact with Aboriginal people, and with the enigmatic character Daisy Bates (1863-1951), who used her base at Ooldea, a remote siding on the Trans-Australia Railway, to study Aboriginal culture and administer medical health care to Aboriginal families gravitating to European settlements from the surrounding bush. In the words of Herbert's son Garth: 'Dad was won over by Ms. Bates, made a lasting friendship and, of course, managed to buy a number of the artefacts. ${ }^{3}$

JC Williamson's, established in 1881, was regarded as Australia's leading theatre company, showcasing the best Australian and overseas talent. With the opening of the railway in 1919, JC Williamson's began taking its productions across the Nullarbor Plain to Perth. Passing through Ooldea, Browne shot still and moving images (in $9.5 \mathrm{~mm}$ ) of Aboriginal people and their encounters with members of the JC Williamson's theatre troupe. On such tours, the entire production team travelled together, including the actors, chorus and musicians, often taking up the whole train. Film footage shot by Browne in the National Museum Archive shows members of the theatre troupe mingling with Aboriginal people, engaging in light-hearted exchanges and taking part in spear and boomerang throwing demonstrations; an intercultural engagement with the kinds of objects - spears, boomerangs and spearthrowers - that Browne acquired through Daisy Bates and which now reside in the NMA collection.

Ooldea was the site where Browne's interests in Asia and Aboriginal Australia would begin to converge and mingle. In 1923 Browne was touring with Oscar Asche's Chu Chin Chow, one of the most successful productions ever staged in London. Asche amassed a small fortune from the musical, which was later released as a novel and feature film. JC

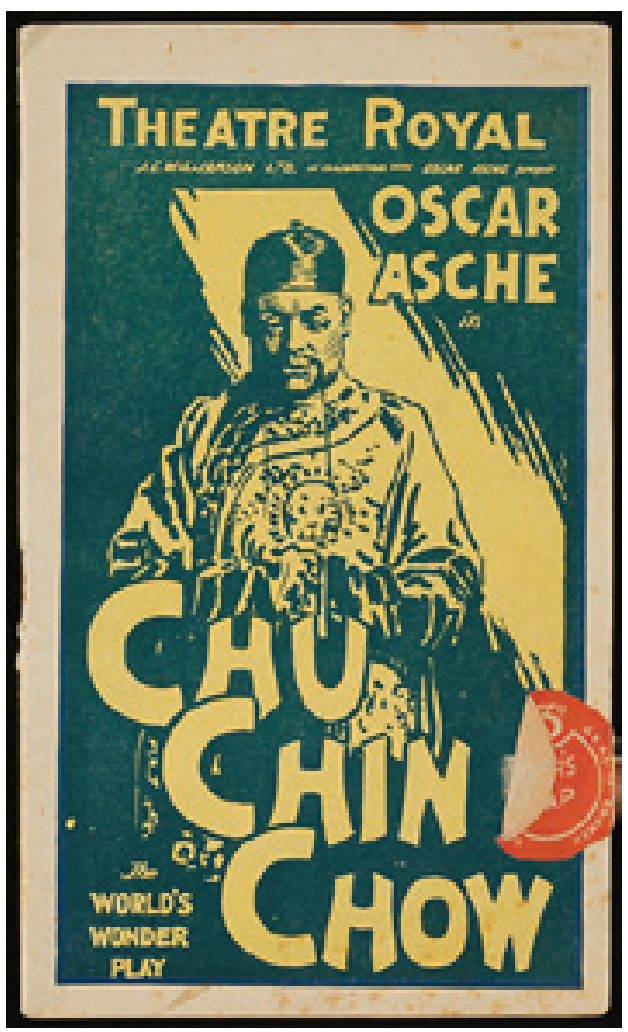

Plate 2. Chu Chin Chow, New Theatre Royal Program 1923, National Museum of Australia. 
Williamson's took over the production in 1921 (Plate 2). Based on the Arabian Nights Ali Baba and the Forty Thieves, Chu Chin Chow blended Arabic and Chinese elements with traditional musical arrangements. Asche played the villain Abu Hasan masquerading as the Chinese merchant Chu Chin Chow, while Herbert Browne was cast as Nur El Hada, Ali Baba's son. Browne later played a similar oriental role, as Sid EI Kar, in a JC Williamson's production of the Romberg-Hammerstein operetta Desert Song. Photographs in the NMA collection show Asche at Ooldea in 1923, the railway siding where Daisy Bates lived for fifteen years from 1919 to 1935.

Some ambiguity surrounds the manner in which the Aboriginal artefacts were transferred from Daisy Bates to Herbert Browne. Browne's connection with Bates and Ooldea was opportunistic; she happened to be at Ooldea when Browne was passing through as a theatre performer. The artefacts are by implication an extension of his theatrical work and would have been nostalgically connected with the trips he made with JC Williamson's cast and crew. Bates was not herself a collector, but often acquired artefacts on behalf of others. While living at Ooldea, she was dismissive of Aboriginal work being produced for sale, commenting that 'the artefacts made today are not worth collecting' (Reece 2007: 94). Another claim made by Bates was that she neither bought nor sold artefacts, reflecting disdain for the commodity status of cultural items.

As would be expected given her view of hybridized objects, the artefacts Browne acquired from Bates are representative of traditional Aboriginal societies prior to contact with Europeans. Some of the items are decorated but most are unadorned utilitarian tool types as would be used by people living in the bush in a traditional manner. Their natural raw materials and pre-modern design distinguish them from his Asian collections which contain objects manufactured with modern techniques and materials. While Browne's Asian collections incorporated aspects of modern manufacture and design, they nonetheless appealed to Browne's narrative of encountering distant cultures and his theatrical view of those cultures as ancient and spiritual. Together, his Aboriginal and oriental collections reflect the desire for an eternalism expressed through an idealised timeless exotic.

In 1937 an article published in The Listener In, records how Browne had: '... built a special "den" for himself, a large room panelled in oak and containing a veritable museum collection of Aboriginal and other curiosities which he has collected in his travels'. ${ }^{4}$ Aboriginal objects were also displayed within the large family dining room, Maggie remembers, where they provided context for relaxed dinner-table conversation. Though there was a degree of separation between Aboriginal and oriental collections, they functioned in similar ways as interior decoration and were both used as props in entertaining rituals. Evoking elements of theatrical and cocktail cultures of the 1920s, the display of items in both collections was intertwined in the transcultural zone that was the Browne family residence. They were, by all accounts, trophies of encounters with exotic people, cultures and races, evoking a sense of travel and worldliness.

Dad would light some incense in the Chinese room and close the doors. He loved to display stuff and create this wonderful ambience for guests. Then afterwards he would open the door and the incense would spill out into the adjacent dining room, which is where he kept his Aboriginal objects while guests were seated at the dinner table. ${ }^{5}$

In Maggie Browne's account, the incense serves as a metaphor for the merging of his Aboriginal and Asian collections. Representing Asian and Aboriginal cultures in adjacent rooms, the Browne family home brought together a convergence of peoples, continents and material culture forms, which came to life through Browne's theatrical background and persona as convivial host.

Browne's collection highlights the manner in which objects are engaged and responded to performatively in the context of the domestic interior. The French philosopher Merleau-Ponty (1945) posited that thought is structured by the human body and its interaction with lived spaces. By maintaining collections which resonated with his professional life as a stage performer, Brown re-lived his connection with the theatre in the home environment.

Herbert Browne's collections made possible the creation of a domestic space which combined opportunities to socialize and entertain with the dissemination of cultural meanings- 
by experiencing the identity of an imaginary Other through the body, and projecting that experience into the field of interpersonal relationships. In the home, as in the theatre, cultures were displayed and performed in a constructed space among family and intimate friends.

While Browne's collection is specific to his role as a performer and carries a particular theatricality, the display of culture as interior decoration and its potential to evoke a sense of Asia went hand-in-hand with changes in domestic activity in the twentieth century, which saw decorating increasingly directed toward comfort and leisure (Ward 2004). Browne's Chinoiserie parlour was a cocktail room as well as a designated space for his collections. For Browne, the cocktail party was a setting in which culture was performed and identities were transposed. When Browne entered his Chinese Room he possibly re-imagined himself as Chinese. Immersed in Chinese objects, Pierson (2007: 72) has noted that collectors would sometimes view themselves as Chinese. This may well have been part of the appeal of the Chinese room collection for Browne, an actor who regularly transformed his identity crossculturally on stage. Through performances, both public and private, and collections of objects arranged architecturally in various locations in the home environment, Europeans came to embody other selves and convey particular understandings of Asia and the world.

\section{The Body, Performance and Representation}

Herbert Browne's collection provides an opportunity to further examine the role of objects and the body in orientalist representation. Said (1978) saw orientalism as an ideology which promoted Europe's interests abroad during its period of global expansion. Orientalism was thus conceived as an abstraction of lived space. Said's model was informed primarily by textual analysis of eighteenth and nineteenth century literature. Performance provides a different point of access for understanding orientalism by situating the representation in the body.

It was literally through the body that Europe came to understand its position in the world. In the nineteenth century, museums were instrumental in the emergence of anthropology as a discipline and the incorporation of material culture with the scientific study of human anatomy and phrenology. Cultural performances also became a vehicle for the dissemination of ideas around the body. Displays were staged in public spaces involving living people from around the world engaged in performances of artefact making and ritual. Bennett (2004: 14) observes, however, that museums sought to distance themselves from the practice of live cultural performance. Museums deployed artefacts and skeletal remains, as opposed to live people, in marrying the depiction of the body with evolutionary theory and colonial geography. The representational frame of the museum was concerned with authentically reproducing cultures through object displays.

Orientalism fashioned ideas about the body as an object of contemplation, detached and distant from the self. Orientalist representation, Said (1978: 55) maintained, '[helps] the mind to intensify its own sense of itself by dramatizing the distance and difference between what is closer to it and far away'. Bodily experience, according to Merleau-Ponty (1945), brings thought into being. In the sense in which it was contemplated in museum displays, the body is relegated to the state of an object, rather than the pivot through which thought arises. For Merleau-Ponty, on the other hand, meaning is assimilated through the body and through lived experience. This opens up the possibility of a more dynamic process of interaction between cultures. Indeed, a criticism of Said's model is that orientalism is seen from only one side - the side generating the representation (Aravamudan 2012, Cook 2007).

Europe's global expansion generated intercultural engagements in which objects, people and ideas moved and co-existed. A large number of British nationals visited and eventually settled in China, India, Japan and Australia during the Empire's colonial expansion. Australia was contacted from early in the seventeenth century, when European vessels began to frequent Australia's western coastline whilst transporting goods between Asia and Europe. ${ }^{6}$

Over the course of the nineteenth century, cultural flows were increasingly mediated by both itinerants and those who came to live and work on a more permanent basis outside their country of origin. Cultural specialists exerted a powerful influence on the objects brought back for public and private consumption, as did Asian traders and dealers operating out of both local and European centres (Richards 2007:135). 
Europeans who encountered Asia and Australia as itinerants and settlers served as intermediaries between their host cultures and those who remained at home. For the vast majority of Europeans, contacts with Asia and Australia remained outside direct experience, yet the materiality of collections allowed cultural encounters to take place in the absence of largescale population shifts. These encounters saw the distinction between cultures increasingly eroded, as material forms were constantly redefined by imitation and recontextualization.

Musical theatre developed within this climate. Orientalist musical theatre was a hybrid form which transposed identities in various ways. A tolerance of hybrid identities is evident through the blending of exotic cultures and locations, the use of transcultural narratives and the adoption of oriental make up and dress by performers. Returning to Merleau-Ponty, musical theatre as an embodied form of representation took place within 'a space of expressiveness' (1945:168). The interpretation of theatrical performance is built into the structure of bodily experience and is inseparable from it. It is not the detached view of a spectator whose gaze is focussed on an object. The live engagement between actor and audience frames the meaning of the performance in any given moment.

In musical theatre, actors moved freely between cultures and locations made possible by the creation of elaborate costumes and sets. Ziter (2003) suggests there was a close relationship between the development of stagecraft and knowledge of geography during the nineteenth century. The ability to depict multiple locations supported the delivery of transcultural narratives. Theatre sets became increasingly sophisticated, allowing audiences to enter imaginary scenes with a heightened sense of reality. Browne recalled an event which happened in 1907 when he was just eleven years old, and already touring with the actor Herbert Tree. It was during a performance of His Majesty's Theatre production of Anthony and Cleopatra that,

The overture played and then the theatre blacked out. The curtain lifted away and there in the darkness appeared the front of a Sphinx, which slowly filled the entire stage ... It shimmered for a couple of seconds and then blacked out and in 5 seconds the lights came on to the scenery of the first act without any Sphinx. The effect was produced by hanging gauzes, which had the Sphinx painted on them about 3 feet apart and the light slowly focused on each gauze until the stage seemed full of the stone Sphinx! When they blacked out all light, the gauzes were pulled up out of vision and uncovered the scenery which had been pre-set. I must point out now that at that time our house in London (4 stories) and the streets, had no electric light . ${ }^{7}$

In The Mikado, English actors were made up to loosely appear Japanese with costumes resembling native dress. Immersed in material representations of Asia, actors, like collectors, were able to imagine and present themselves as Asian. However, racial imitation in the theatre was not about trying to authentically reproduce race, as Yoshihara (2002: 79) has noted. Actors blended their own selves with their stage characters producing a hybrid form. Orientalist theatre was a site for imaginative exploration rather than authentic reproduction, which enabled boundaries between cultures to be transcended (Aravamudan 2012). These kinds of creative exploration took place in a context of growing anxiety surrounding race (Walker 1999).

In November 1919 before leaving England for Australia, Brown appeared in The Mikado ${ }^{8}$ at the Parish Hall, Golders Green, London, as Nanki-Poo, a role he was later to play in the same musical in Australia for the JC Williamson's Company. ${ }^{9}$ Browne's daughter Maggie and son Garth recalled how the role of Nanki-Poo became for their father an extension of his personal identity, and how he would assume the character in the context of convivial home entertainment in the company of his children and invited guests. ${ }^{10}$

Prior to leaving for Australia in 1921, Herbert Browne had not visited Asia. Neither had Browne developed a detailed knowledge of specific Asian cultures or languages over the course of his career. As Lowenthal (1985: 7) once reminded us, 'one need not go abroad to taste the exotic'. As a non-specialist Browne was not in a position to acquire what might be considered 'authentic' Asian items, as represented in museum collections, unless he received advice from a knowledgeable insider, as he did in the case of his Aboriginal artefacts obtained through Daisy Bates. There is, however, no indication he received this kind of advice in regard to his Asian collection. Browne was not a scholar whose contemplation of material culture involved 


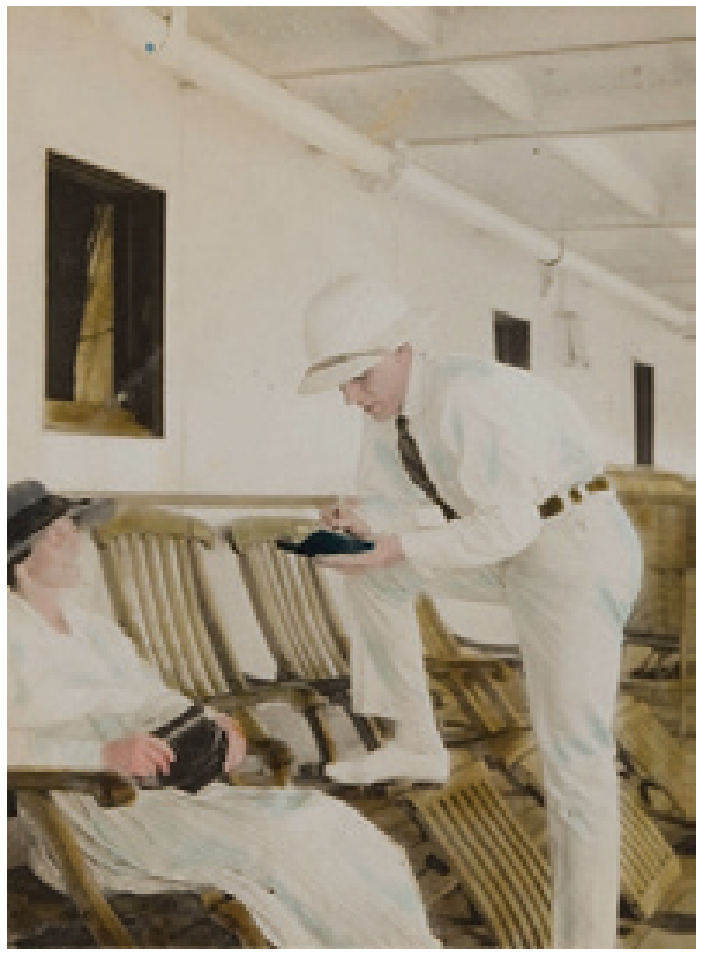

Plate 3. Herbert Browne aboard the ship on which he travelled to Australia in 1921, National Museum studious cataloguing or documenting of objects. Instead his interests in Asia were stimulated through the theatre and contact with the wider cosmopolitan society in which he circulated.

Browne was the product of an English background which experimented with what it might be like to be Asian while remaining at home during the Empire's global military and economic expansion in the nineteenth and early twentieth centuries. Growing up in London, the young Browne would have had contact with a broad range of social media, including museums, where Asian and Other cultures were widely in the public view, exposing him to the materiality and aesthetics of life 'beyond the frontier'. En route to Australia, Browne most likely travelled via the Suez Canal and would have experienced stopovers at several ports in Africa and Asia. In a photograph of him taken on his voyage to Australia in 1921 Browne appears in white tropical suit and solar topee, the familiar tropes of a colonial 'on safari' (Plate 3 ). Before embarking on this journey, he had no actual experience of Asia but had been immersed in a society highly inflected with colonial cultures. From the time of leaving England his life is punctuated by experiences of frontier contact. In his

migration journey to Australia and as a member of JC Williamson's troupe travelling across central Australia, he encounters colonial life first hand. At Ooldea railway siding, then home to Daisy Bates, he experiences contact with Aboriginal culture.

Aboriginal people for their part were drawn to Ooldea for its European goods and often mingled with train passengers and railway workers, an engagement condemned by Daisy Bates who strongly favoured racial separation. Bates, who prided herself that 'No more half-caste children were born in Ooldea from 1920 onward until the temporary cessation of my work there in 1934' (Bates 1947: 192), considered Aboriginal people 'lawless' and in need of 'the governance and fatherhood of Empire-makers, men of sterling British type that brought India and Africa into our Commonwealth of Nations' (Bates 1947: 237-8).

As the outcome of a series of acquisitions, Browne's collection brings into focus the the meanings embedded in collection and acquisition processes and their transformation as objects change hands. It was the connection with Bates which prompted the NMA to acquire Browne's Aboriginal artefacts and which in turn led to the acquisition of his oriental collection. The teasing out of the relationship between Browne's Aboriginal and oriental material has potential to throw additional light on the way in which interest in Aboriginal and Asian cultures came together in the national imaginary. Daisy Bates and Oscar Asche, who were significant in the formation of Anglo-Australian representations of Aboriginal and oriental identities, were connected through Ooldea and though the collections of Herbert Browne. Ooldea provides another potential point of entry into this history as a site where early-contact Aboriginal culture and global cosmopolitanism meet. 


\section{Notes}

1 Maggie Browne, personal communication, 21 February 2007.

2 School of Japanese art which emerged in the Momoyama period (1568-1615)

3 Email to Peter Thorley from Sotheby's 24 October 2006.

4 Radio announcer with a dual personality, The Listener In, No. 5, 30 October 1937.

5 Maggie Browne, personal communication, 21 February 2007.

6 Porcelain recovered from Dutch wrecks off the Australian coastline is displayed in the NMA's Australian Journeys gallery.

7 The Basin Theatre Group Newsletter, January 1975.

8 Theatre Program The Mikado, 26-29 November 1919.

9 The Mikado draws upon Japanese visual elements and settings to fashion a thinly veiled critique of British institutions, the nobility and the monarchy.

10 Maggie Browne, personal communication, 21 February 2007.

\section{Acknowledgements}

The task of researching this collection has been made easier by the assistance of a number of individuals. I owe the greatest debt to Maggie and Garth Browne, whose unstinting efforts to help me piece together the puzzle of their father's life have been invaluable. Sadly, Garth Browne passed away in 2007. Since then, Maggie organised the transfer of the bulk of the collection to the NMA and has given generously of her time to assist with its documentation. The Registration staff at NMA provided a comprehensive description and photographic record of the collection. NMA librarians Naomi Newton and Noellen Newton were helpful and attentive to my numerous requests. Jonathon Lineen introduced me to the delights of Merleau-Ponty. Melanie Eastburn (National Gallery of Australia) and Carol Cains and Matthew Martin (National Gallery of Victoria) assisted with object identifications.

\section{References}

Altshuler, B. (2007) 'Collecting the new: a historical introduction', in B. Altshuler (ed.) Collecting the New: Museums and Contemporary Art, 1-14, Princeton: Princeton University Press.

Aravamudan, S. (2012) Enlightenment Orientalism: Resisting the Rise of the Novel, Chicago: University of Chicago Press.

Bates, D. (1947) The Passing of the Aborigines, London: John Murray.

Bennett, T. (2004) Pasts Beyond Memory: Evolution, Museums, Colonialism, London: Routledge.

Bolton, L. (2008) 'Living and dying: ethnography, class and aesthetics in the British Museum', in D. J. Sherman (ed.), Museums and Difference, 330-353, Bloomington: Indiana University Press. 
Cheang, S. (2001) 'The dogs of Fo: Gender, Identity and Collecting', in A.W. Shelton (ed.) Collectors: Expressions of Self and Other, 55-72, London: Horniman Museum.

Clifford, J. (1997) Routes: Travel and Translation in the Late Twentieth Century, Cambridge: Harvard University Press.

Cook, N. (2007) 'Encountering the Other, redefining the self: Hindostannie airs, Haydyn's folk song settings and the 'common practice' style', in M. Clayton and Z. Bennett (eds.) Music and Orientalism in the British Empire, 1780s-1940s, 13-37, Aldershot: Ashgate.

Desai, V. N. (2007) 'Beyond the "authentic-exotic": collecting contemporary Asian art', in B. Altshuler (ed.) Collecting the New: Museums and Contemporary Art, 103-114, Princeton: Princeton University Press.

Everett, W.A. (2007) 'Chu Chin Chow and orientalist musical theatre in Britain during the First World War', in M. Clayton and Z. Bennett (eds.) Music and Orientalism in the British Empire, 1780s-1940s, 277-296, Aldershot: Ashgate.

Harris, C. (2006) 'The Buddha goes global: some thoughts toward a transnational art history', Art History 29(4) 698-720.

Jacobson, D. (1993) Chinoiserie, London: Phaidon.

Lockyer, A. (2008) 'National museums and Other cultures in Modern Japan', in D. J. Sherman (ed.) Museums and Difference, 97-123, Bloomington: Indiana University Press.

Lowenthal, D. (1985) The Past is a Foreign Country, Cambridge: Cambridge University Press.

Merleau-Ponty, M. (1945) Phenomenology of Perception (Translated in 1958), London: Routledge.

Myers, F.R. (2001) 'Introduction', in F.R. Myers (ed.) The Empire of Things: Regimes of Value and Material Culture, 3-61, Santa Fe: School of American Research Press.

National Museum of China (2011) National Museum of China, London: Scala Publishers.

O'Hanlon M. and Welsch R.L (2000) Hunting the Gatherers: Ethnographic Collectors, Agents and Agency in Melanesia, 1870s-1930s, New York: Berghan Books.

Peterson, N., Allen L and Hamby L. (2008) The Makers and Making of Indigenous Australian Museum Collections, Melbourne: Melbourne University Press.

Phillips, R. B. and Steiner. C.B. (eds.) (1999) Unpacking Culture: Art and Commodity in Colonial and Postcolonial Worlds, Berkeley: University of California Press.

Pierson, S. (2007) Collectors, collections and museums: the field of Chinese ceramics in Britain, 1560-1960, Peter Lang: Oxford.

Reece, R. (2007) Daisy Bates: Grand Dame of the Desert, Canberra: National Library of Australia.

Richards, F. (2007) 'Granville Bantock and the orient in the Midlands', in M. Clayton and Z. Bennett (eds.) Music and Orientalism in the British Empire, 1780s-1940s, 129-146, Aldershot: Ashgate. 
Said, E.W. (1978 (2003)) Orientalism, London: Penguin.

Shelton, A.W. (ed.) (2001) Collectors: Expressions of Self and Other, London: Horniman Museum.

Tythacott, L. (2001) 'From the fetish to the specimen: The Ridyard African collection at the Liverpool Museum 1895-1916', in in A.W. Shelton (ed.) Collectors: Expressions of Self and Other, 157-180, London: Horniman Museum.

Tythacott, L. (2011) The Lives of Chinese objects: Buddhism, Imperialism and Display, Oxford, New York: Berghahn Books.

Walker, D. (1999) Anxious Nation: Australia and the Rise of Asia 1850-1939, St Lucia: University of Queensland Press.

Ward, L. (2004) 'Chintz, swags and bows: the myth of English country-house style, 193090', in S. McKellar and P. Sparke (eds.) Interior Design and Identity, Manchester: Manchester University Press.

Yoshihara M. (2002) Embracing the East: White Women and American Orientalism, Oxford: Oxford University Press.

Ziter, E. (2003) The Orient on the Victorian Stage, Cambridge: Cambridge University Press.

\section{*Peter Thorley}

Dr Peter Thorley is currently acting head of the Aboriginal and Torres Strait Islander Program, National Museum of Australia. He has worked extensively in Indgenous communities and in developing and interpreting Indigenous cultural material since the late 1980s. His research interests revolve around the interpretive practices of museums and the role of material culture in the national imaginary.

Dr Peter Thorley

Acting Head

Aboriginal and Torres Strait Islander Program

National Museum of Australia

T +61 (0)2 62085242

peter.thorley@nma.gov.au 